\title{
Cost Effective Technology of Alunite Ore Processing
}

\author{
Eldar I. Taghiyev ${ }^{1}$, Elšad Tagijev ${ }^{1}$, Lale Agajeva ${ }^{1}$ \\ ${ }^{1}$ Azer plus, Prague, Czech Republic \\ Correspondence: Eldar I. Taghiyev, Kotršálova 301/12, 19600 Prague, Czech Republic, E-mail: eltag@tiscali.cz, \\ elshad@tiscali.cz
}

Received: February 10, 2019 Accepted: March 17, 2019 Online Published: March 20, 2019

doi:10.5539/ijc.v11n1p36

URL: https://doi.org/10.5539/ijc.v11n1p36

\begin{abstract}
Soda-alkaline method of alunite ore processing includes crushing, grinding and enrichment (flotation) of the alunite ore. Enriched alunite ore, containing $50-60 \%$ of alunite, is roasted at temperatures between $520^{\circ}-620^{\circ} \mathrm{C}$ for $1-3$ hours. Roasted alunite is further leached with sodium carbonate solution (5-20\%). Proportion of sodium carbonate for binding of $\mathrm{SO}_{3}$ aluminum sulfate in alunite accounts for $100-110 \%$ of stoichiometric quantities. Leaching takes place at temperatures around $70-100^{\circ} \mathrm{C}$ for $0.5-2.0$ hours. Solution of the resulting pulp contains all the potassium sulfate from alunite and sodium sulfate from soda. Solution of sulfates is separated from the insoluble residue and is fed for conversion with potassium chloride. As result of this conversion we obtain quantities of potassium sulfate (fertilizer) and table (common) salt. The remaining insoluble residue contains all the aluminum oxide from alunite and waste rock. Further processing of the insoluble residue based on the Bayer out-of-autoclave process produces alumina and quartz sand. Besides alumina, this method makes it possible to get four times more the amount of potassium sulfate and certain volumes of table salt.

Taking into account the processing capacity of Ganja Alumina Plant (150,000 tons of alumina per year), this method allows the production of fertilizer, potassium sulfate $(370,000$ tons per year), coagulant for purification of water from mechanical impurities $(49,000$ tons per year), table salt $(\mathrm{NaCl})(126,000$ tons per year), and quartz sand for non-ferrous casting and production of construction materials (300,000 tons per year). Approximate yearly financial efficiency of the soda-alkaline technology for processing of 150,000 tons of alumina per year will be around 171,46 million USD.
\end{abstract}

Keywords: alumina, alunite, aluminum, alkaline, sodium, ore, sulfate, potassium, technology

\section{Introduction}

Nowadays more than $90 \%$ of primary aluminum is produced from bauxite, however the amount of aluminum in the explored bauxite ore deposits accounts for less that $10 \%$ of world reserves. The huge demand for alumina has led to a switch of definitions of raw aluminum materials in the world economy. Currently, primary raw materials for aluminum production include bauxite, alunite, nepheline and nepheline syenite, certain types of clay and shale, as well as ashes from thermal power plants that use coal. The deposits of alunite ores are widespread in the Earth's crust. According to the map of alunite deposits and occurrences, compiled by academician M.A. Kashkai (Kashkai, 1970), industrial deposits of alunite ores are mainly located in the alpine zone, which starts in the Eastern China, then continues through Middle Asia, Caucasus and Transcarpathia to the Mediterranean basin (i.e. within Southern Europe and Northern Africa). Further on, the alunite zone passes across the Atlantic Ocean into North America and the southern part of the United States.

Alunite ore is a raw material for the chemical and aluminum industries. Industrial deposits of alunite ores are widespread in the USA, China, Azerbaijan, Mexico, Iran, Kazakhstan, Uzbekistan, Ukraine, Russia, and other countries.

This article is devoted to a technology of integrated processing of alunite ores, resulting in production of chlorine-free potassium fertilizer - potassium sulfate (SOP), metallurgical alumina, coagulant for purification of drinking and wastewater from mechanical impurities, table salt - sodium chloride $(\mathrm{NaCl})$ and quartz sand for non-ferrous casting and production of construction materials.

2. There exists an alkaline recovery method of alunite ores processing (Agranovskiy, 1970), in which ore after crushing, grinding and roasting is subject to a recovery roasting at temperatures of $\leq 560-580^{\circ} \mathrm{C}$ by the reaction:

$\mathrm{K}_{2} \mathrm{SO}_{4} \cdot \mathrm{Al}_{2}\left(\mathrm{SO}_{4}\right)_{3} \cdot 2 \mathrm{AL}_{2} \mathrm{O}_{3}+0,5 \mathrm{C}_{2} \mathrm{H}_{4}=3 \mathrm{AL}_{2} \mathrm{O}_{3}+\mathrm{K}_{2} \mathrm{SO}_{4}+3 \mathrm{SO}_{2}+\mathrm{CO}_{2}+\mathrm{H}_{2} \mathrm{O}$

Main reducing agents for the reaction are diesel fuel or sulfur in gaseous form. $\mathrm{SO}_{2}$, resulting from the reaction, is used 
for production of sulfuric acid. The complete process of recovery takes place at temperatures over $580^{\circ} \mathrm{C}$. This method was applied at Ganja Alumina Plant (GAP) (Azerbaijan). Due to serious technological drawbacks (low yield of alumina in the product - less 70\%; damage to the environment due to dust and gas pollution; the need for expensive auxiliary raw materials; large amounts of solid waste -5 tons per 1 ton of alumina; low demand for the by-product - sulfuric acid) the plant was shut down in 1992 and is still not working.

3. These drawbacks can be avoided by applying the potash-alkaline method (Lajner- Taghiyev) (Lajner, 1974), (Taghiyev, 1981, 2001, 2003, 2006). Alunite, roasted at $\mathrm{T}=550^{\circ} \mathrm{C}$ without recovery is leached by potassium carbonate solution by the reaction:

$\mathrm{K}_{2} \mathrm{SO}_{4} \cdot \mathrm{AL}_{2}\left(\mathrm{SO}_{4}\right)_{3} \cdot 2 \mathrm{AL}_{2} \mathrm{O}_{3}+\mathrm{wr}+3 \mathrm{~K}_{2} \mathrm{CO}_{3}=4 \mathrm{~K}_{2} \mathrm{SO}_{4}+3 \mathrm{AL}_{2} \mathrm{O}_{3}+\mathrm{wr}+3 \mathrm{CO}_{2}(\mathrm{wr}-$ waste rock)

Solution contains 4 times more potassium sulfate (SOP), and the insoluble residue contains active alumina $\left(¥-\mathrm{AL}_{2} \mathrm{O}_{3}\right)$. Insoluble residue is then processed, using the Bayer out-of-autoclave process, and produces alumina and quartz sand. The yield of alumina in the product is- $90 \%$. White slurry of process desiliconization goes to production of coagulant for water purification. The major drawback of this method is related to use of high volumes of potassium carbonate, a scarce and expensive auxiliary raw material.

4. Potash Ridge Corporation (PRC) from Utah, USA has developed another processing method (PRC, 2017) for production of sulfuric acid, potassium sulfate (SOP), alumina, quartz sand from alunite ore. After crushing and roasting the alunite ore is subject to a floatation treatment. As a result, the ore contains not less than $60 \%$ of alunite. Then the ore is dried and roasted at $600^{\circ} \mathrm{C}$ or below with a simultaneous alunite recovery by adding of excess diesel fuel. The emitted $\mathrm{SO}_{2}$ is supplied to the production of sulfuric acid, which is further used by PRC for processing of $\mathrm{KCl}$ at the deposit in Quebec (Canada) and obtaining additional quantities of fertilizer $\mathrm{K}_{2} \mathrm{SO}_{4}$ and hydrochloric acid ( $\mathrm{HCl}$ ). Roasted alunite is leached by the hot water for extraction of potassium sulfate in the solution (SOP). Roasting temperatures less than $600^{\circ}$ $\mathrm{C}$ result in incomplete recovery of alunite, however allows the maintenance of an active form of alumina in alunite. Still, leaching of alunite, roasted at $600^{\circ} \mathrm{C}$ by hot water leads to SOP losses due to formation of basic salt, insoluble in water. Share of SOP in the solution does not exceed $65-70 \%$. Roasting at $800-900^{\circ} \mathrm{C}$ improves the alunite recovery proportion up to $100 \%$ with extraction of $\mathrm{SO}_{3}$ by aluminum sulfate. At the same time, the share of SOP is close to $100 \%$, however $¥-\mathrm{AL}_{2} \mathrm{O}_{3}$ changes into an insoluble form $\alpha-\mathrm{AL}_{2} \mathrm{O}_{3}$. Consequently, Bayer method of alumina extraction from the concentrate cannot be applied. There are no known methods of separation of $\alpha-\mathrm{AL}_{2} \mathrm{O}_{3}$ and quartz in an insoluble residue, resulting in production of metallurgical alumina.

5. In order to eliminate these drawbacks and improve economic and ecological performance, we offer to perform leaching of the roasted alunite in two stages, as described in (Lajner, 1974) and replace potassium carbonate solution by the sodium carbonate solution at the first stage of leaching (1). After the first leaching the solution- mixture of sodium and potassium sulfates - is fed for conversion with $\mathrm{KCl}$, resulting in the production of potassium sulfate (fertilizer) and table salt $-\mathrm{NaCl}(2)$.

$$
\begin{aligned}
& \text { (1): } \mathrm{K}_{2} \mathrm{SO}_{4} \cdot \mathrm{AL}_{2}\left(\mathrm{SO}_{4}\right)_{3} \cdot 2 \mathrm{AL}_{2} \mathrm{O}_{3}+\mathrm{WR}+3 \mathrm{Na}_{2} \mathrm{CO}_{3}=\mathrm{K}_{2} \mathrm{SO}_{4}+3 \mathrm{Na}_{2} \mathrm{SO}_{4}+\left(3 \mathrm{AL}_{2} \mathrm{O}_{3}+\mathrm{WR}\right)+3 \mathrm{CO}_{2} \\
& \text { (2): } \mathrm{K}_{2} \mathrm{SO}_{4}+3 \mathrm{Na}_{2} \mathrm{SO}_{4}+6 \mathrm{KCl}=4 \mathrm{~K}_{2} \mathrm{SO}_{4}+6 \mathrm{NaCl},
\end{aligned}
$$

$\left(3 \mathrm{AL}_{2} \mathrm{O}_{3}+\mathrm{WR}\right)$ - Insoluble residue concentrate $\left(32-34 \% \% \mathrm{AL}_{2} \mathrm{O}_{3}\right)$ from the first leaching is fed for the second leaching, made with the reusable aluminate solution based on the Bayer out-of-autoclave process. Final products of the process are metallurgical alumina and quartz sand. The yield of alumina in the product is - $90 \%$. The alunite roasting process is performed at $\mathrm{T}^{\circ}=520^{\circ}-550^{\circ} \mathrm{C}$. Roasted alunite is leached by the sodium carbonate solution (Proportion of sodium carbonate for binding of $\mathrm{SO}_{3}$ aluminum sulfate in alunite accounts for $100-110 \%$ of stoichiometric quantities). Products of the reaction are $\mathrm{K}_{2} \mathrm{SO}_{4}$ - fertilizer, $\mathrm{NaCl}$ - table salt, $\mathrm{Al}_{2} \mathrm{O}_{3}$-metallurgical alumina, $\mathrm{SiO}_{2}$ - quartz sand, coagulant for purification of water from mechanical impurities (Taghiyev, 1976). Thus, an ecologically harmful production of sulfuric acid can be excluded from the process. Conversion of the solution of sodium sulfate with $\mathrm{KCl}$ from a deposit in Quebec (Canada) leads to production of $\mathrm{K}_{2} \mathrm{SO}_{4}(\mathrm{SOP})$ and $\mathrm{NaCl}$. Volume of production of a universal and chlorine-free potassium fertilizer (SOP) is increased 4 times- (Appendix A).

The conversion of the $\mathrm{Na}_{2} \mathrm{SO}_{4}$ with $\mathrm{KCl}$ is a well-known process of obtaining $\mathrm{K}_{2} \mathrm{SO}_{4}$ and $\mathrm{NaCl}$ (N. V. Nemets, 1995). From literature (M. E. Posin, 1974) it is known that the process of conversion of natural $\mathrm{KCl}$ and $\mathrm{Na}_{2} \mathrm{SO}_{4}$ with obtaining $\mathrm{K}_{2} \mathrm{SO}_{4}$ and $\mathrm{NaCl}$ was used in Canada. Conversion takes place in two stages: at the first stage as a result of evaporation $\mathrm{NaCl}$ is obtained. Glasurit and $\mathrm{KCl}$ remain in the solution. When cooled to a temperature below $40^{\circ} \mathrm{C}, \mathrm{K}_{2} \mathrm{SO}_{4}$ precipitates, and the mother solution returns to the first stage.

The Ganja Alumina Plant (GAP) uses a mixture of potassium and sodium alunite as raw material. Therefore, for the transfer of sodium sulfate to potassium sulphate, the conversion of sodium sulfate with potash alkali was applied. As a result, potassium sulfate and sodium alkali were obtained. The conversion process did not significantly affect the cost of 
the main products.

In the article (Alizadeh, 2016) the choice of optimal technology of alunite ore with the use of AHP and TOPSIS based on three criteria: technical, economic and environmental is being developed. From the 13 technology options, (Piga L, 1999) technology was chosen. However, to be sure of the correctness of this decision, the experimental confirmation and full disclosure of the technology with the material balance is required.

Note 1 . USA is $2^{\text {nd }}$ largest producer of soda ash in the world, and Canada is the world's largest producer of potassium chloride $(\mathrm{KCl})$.

Technical and Economic Indicators of SodA-Alkaline Technology of Processing ALunite Ores

Note 2. Economic calculation is made for alunite ores, enriched mechanically up to the $50-51 \%$ of alunite in the ore (field Zaglik, Azerbaijan)

The average chemical composition of alunite ore of Zaghlik, weight, \%:

\begin{tabular}{cccccccc}
\hline $\mathrm{AL}_{2} \mathrm{O}_{3}$ al & $\mathrm{AL}_{2} \mathrm{O}_{3 \text { nonal }}$ & $\mathrm{SO}_{3}$ & $\mathrm{Na}_{2} \mathrm{O}$ & $\mathrm{K}_{2} \mathrm{O}$ & $\mathrm{SiO}_{2}$ & $\mathrm{Fe}_{2} \mathrm{O}_{3}$ & other \\
\hline 19.2 & 2.5 & 20.0 & $1.5-2.0$ & $3.5-4.0$ & $42-43$ & $4-5$ & $7.3-4.3$
\end{tabular}

Calculation of Economic Efficiency of Soda- Alkaline Processing Technology of Alunite Ores for Production Capacity of 150,000 Tons of Alumina Per Year

Calculation of costs is made per each ton of alumina.

Note 3. Prices of manufactured goods and raw materials were calculated as an average between the minimum and maximum wholesale prices, taken from the Internet as of October 09, 2018 (in USD per ton)

\begin{tabular}{cllll} 
& $\mathrm{Na}_{2} \mathrm{CO}_{3}$ & $\mathrm{Min}$ & 311.26 & $\mathrm{Na}_{2} \mathrm{CO}_{3}$ Average price \\
& $\mathrm{Max}$ & 328.55 & $320 \mathrm{USD} /$ ton \\
$\mathrm{KCl}$ & $\mathrm{Min}$ & 291.3 & $\mathrm{KCl}$ Average price \\
& $\mathrm{Max}$ & 349.3 & 317.3 USD/ton \\
& $\mathrm{Min}$ & 591.4 & $\mathrm{~K}_{2} \mathrm{SO}_{4}$ Average price \\
$\mathrm{K}_{2} \mathrm{SO}_{4}$ & $\mathrm{Max}$ & 754.0 & 672.7 USD/ton \\
& $\mathrm{Min}$ & 104.0 & $\mathrm{NaCl}$ Average price \\
& $\mathrm{NaCl}$ & Max & 126.5 & 115.25 USD/ton \\
& $\mathrm{Min}$ & 570.6 & $\mathrm{~K}_{2} \mathrm{CO}_{3}$ Average price \\
& $\mathrm{K}_{2} \mathrm{CO}_{3}$ & Max & 726.27 & $648.4 \mathrm{USD} /$ ton \\
\hline
\end{tabular}

GAP - Ganja Alumina Plant

Table 1. Costs of raw and basic materials (Section 1)

\begin{tabular}{rrrrrr}
\hline & \multicolumn{1}{c}{ Item } & Unit & $\begin{array}{c}\text { Necessary quantity for } \\
\text { production of } 1 \text { ton of } \mathrm{AL}_{2} \mathrm{O}_{3}\end{array}$ & $\begin{array}{c}\text { Unit cost } \\
\text { in USD }\end{array}$ & $\begin{array}{c}\text { Total in } \\
\text { USD }\end{array}$ \\
\hline 1 & Alunite ore $(51 \%$ of alunite) & ton & 5.7 & 6.3 & 35.91 \\
2 & Sodium carbonate $\left(\mathrm{Na}_{2} \mathrm{CO}_{3}\right)-100 \%$ & ton & 1.12 & 320.0 & 358.4 \\
3 & Potassium chloride $(\mathrm{KCL}-100 \%)$ & ton & 1.19 & 317.3 & 377.59 \\
4 & Sulfuric acid (concentrated, 92 -94\%) & ton & 0.3 & 30.0 & 9.0 \\
& Total costs Section 1 & & & & 780.9 \\
\hline
\end{tabular}


Table 2. Costs of auxiliary materials (according to GAP)

\begin{tabular}{rrrrrr}
\hline & \multicolumn{1}{c}{ Item } & Unit & $\begin{array}{r}\text { Necessary quantity for production of } 1 \\
\text { ton of. } \mathrm{AL}_{2} \mathrm{O}_{3}\end{array}$ & $\begin{array}{c}\text { Unit cost in } \\
\text { USD }\end{array}$ & $\begin{array}{c}\text { Total in } \\
\text { USD }\end{array}$ \\
\hline 1 & Steel spheres & $\mathrm{kg}$ & & 11.5 & \\
2 & Filtering cloth & $\mathrm{sq.} \mathrm{m}$ & 0.1 & Based on information on \\
3 & Coagulant (flour) & $\mathrm{kg}$ & 4.0 & 6.0 & expenditures, provided by \\
4 & Cellulose & $\mathrm{kg}$ & 6.0 & GAP \\
5 & Paper for recycling & $\mathrm{kg}$ & 6.0 &
\end{tabular}

Total costs Section 2

Table 3. Costs of electric power and fuel

\begin{tabular}{|c|c|c|c|c|c|}
\hline & Item & Unit & $\begin{array}{c}\text { Necessary quantity for } \\
\text { production of } 1 \text { ton of. } \mathrm{AL}_{2} \mathrm{O}_{3}\end{array}$ & $\begin{array}{l}\text { Unit cost in } \\
\text { USD }\end{array}$ & $\begin{array}{l}\text { Total in } \\
\text { USD }\end{array}$ \\
\hline 1 & Black oil or gas for roasting alunite & $\mathrm{T}$ & 0.174 & 63 & 10.96 \\
\hline 2 & Black oil or gas for calcination & $\mathrm{T}$ & 0.115 & 63 & 7.25 \\
\hline 3 & Electric power x 1000 & kwh & 1.6 & 30 & 48 \\
\hline 4 & Water x 1000 & $\begin{array}{c}\mathrm{sq} \\
\mathrm{m}\end{array}$ & 0.35 & 8.9 & 3.12 \\
\hline 5 & Steam & Kcal & 4.0 & 2.1 & 8.4 \\
\hline 6 & Compressed air x1000 & $\begin{array}{l}\mathrm{sq} \\
\mathrm{m}\end{array}$ & 2.1 & 5.0 & 10.5 \\
\hline & Total costs Section 3 & & & & 88.23 \\
\hline
\end{tabular}

Table 4. Costs of auxiliary materials and amortization

\begin{tabular}{|c|c|c|c|c|c|}
\hline & Item & Unit & $\begin{array}{l}\text { Necessary quantity for } \\
\text { production of } 1 \text { ton } \\
\text { of. } \mathrm{AL}_{2} \mathrm{O}_{3}\end{array}$ & $\begin{array}{l}\text { Unit cost in } \\
\text { USD }\end{array}$ & $\begin{array}{l}\text { Total in } \\
\text { USD }\end{array}$ \\
\hline 1 & $\begin{array}{l}\text { Amortization of the equipment, } \\
\text { buildings and other constructions }\end{array}$ & & & & 3.4 \\
\hline 2 & Packing of $\mathrm{K}_{2} \mathrm{SO}_{4}($ per $50 \mathrm{~kg})$ & pcs & 49 & 0.22 & 10.78 \\
\hline \multirow[t]{2}{*}{3} & Packing of $\mathrm{AL}_{2} \mathrm{O}_{3}$ (per 1 ton) & & & & 5.0 \\
\hline & Total costs Section 4 & & & & 19.18 \\
\hline
\end{tabular}

Table 5. Wages and other expenses

\begin{tabular}{rrrrr}
\hline & Item & Unit & $\begin{array}{r}\text { Necessary quantity for production } \\
\text { of } 1 \text { ton of } \mathrm{AL}_{2} \mathrm{O}_{3}\end{array}$ & $\begin{array}{r}\text { Unit cost in USD } \\
\text { Total in } \\
\text { USD }\end{array}$ \\
\hline 1 & $\begin{array}{r}\text { Wages and social insurance } \\
\text { Ordinary maintenance and other } \\
\text { related expenses } \\
\text { Total costs Section 5 }\end{array}$ & & $21.6+7.8$ \\
\\
\end{tabular}

The total amount of expenses on producing of 1 ton of alumina are equal to USD 929.11

Table 6. Income from sales of by-products of production of alumina (per 1 ton)

\begin{tabular}{|c|c|c|c|c|c|}
\hline & Item & Unit & $\begin{array}{r}\text { Necessary quantity } \\
\text { for production of } 1 \\
\text { ton of } \mathrm{AL}_{2} \mathrm{O}_{3} \\
\end{array}$ & $\begin{array}{r}\text { Unit cost in } \\
\text { USD }\end{array}$ & $\begin{array}{r}\text { Total in } \\
\text { USD }\end{array}$ \\
\hline 1 & Fertilizer $\left(\mathrm{K}_{2} \mathrm{SO}_{4}\right)$ & ton & 2.47 & 672.7 & 1661.6 \\
\hline 2 & Coagulant for water purification & ton & 0.33 & 146 & 48.18 \\
\hline 3 & $\begin{array}{r}\text { Quartz sand for nonferrous molding and building } \\
\text { materials }\end{array}$ & ton & 2.0 & 7.5 & 15.0 \\
\hline 4 & Table salt (NaCL-100 \%) & Ton & 0.845 & 115.25 & 97.4 \\
\hline & \multicolumn{2}{|c|}{ Total income } & USD & & 1822.18 \\
\hline
\end{tabular}


With the average selling price of 1 ton of alumina equaling to USD 250, the total income from sales of the whole will be equal to $=1822.18+250=$ USD 2072.18 .

After subtracting the production costs, the resulting profit will be $=2072.18-929.11=$ USD 1143.07 per each ton of $\mathrm{AL}_{2} \mathrm{O}_{3}$.

Considering the whole production capacity of Ganja Alumina Plant (GAP), equal to 150,000 tons of alumina per year, the resulting profit is estimated to be $1143.07 \times 150,000=$ USD M 171,46 per year.

Note 4. Cost of products for production and raw materials is taken from the Internet, as well as information on production capacities of Ganja Alumina Plant (GAP).

To reduce the capital costs of the implementation of the soda-alkaline technology, the process can be divided into 2 stages.

At the first stage we can implement the part, related to the first leaching of roasted alunite with soda solution $\left(\mathrm{Na}_{2} \mathrm{CO}_{3}\right)$ and separation of the insoluble residue (concentrate) for storage. This solution - a mix of potassium and sodium sulfates - is used for conversion with potassium chloride, obtaining sulfate potassium (SOP) and sodium chloride ( $\mathrm{NaCl}$ ) as result. (see Appendix B). Profit from sales of products from the $1^{\text {st }}$ stage will be directed to construction of the alumina processing part of the plant and implementation of the full-scale soda-alkaline technology.

Note 5. The authors have already received a positive decision on awarding of a patent in the Czech Republic with a priority from January 30, 2018.

\section{References}

Agranovsky, A. A., Kaganovich, Y. Y., \& Labutin, V. G. (1970). The USSR certificate of authorship №106048, Discoveries and inventions, 26, p. 15.

Alizadeh, S. (2016). Alunite processing method selection using the AHP and TOPSIS approaches under fuzzy environment International Journal of Mining Science and Technology, 26, 1017-1023.

Kashkai, M. A. (1970). Alunites their genesis and use. Vol 1-2, Publishing House Nedra, Moscow.

Lajner, A. I., Zakharova, V. I., Popeljukhina, M. I., Lajner, J. A., Taghiyev, E. I., \& Pevzner, I. Z. (1974). The USSR certificate of authorship \# 460709, October 21, 1974

Nemets, N. V., \& Nasyrov, G. Z. (1995). Conversion of a mixture of potassium and sodium sulphates with potassium chloride. The sertificate of authorship of USSR № 784156 from 14.06.1979 g. VAMI, published 10.11.1995.

Piga, L., Pochetti, F., \& Cipriani, P. (1999). Beneficiation of alunite by piro - and hydrometallurgical treatment of alunite $-\mathrm{K}_{2} \mathrm{CO}_{3}$ mixtures. Miner Metall Process, 16(2), $20-24$.

Posin, M. E. (1974). Technology of mineral salts, part 1, Chemistry edition, 792

Potash, R. (2017). Corp, Technical Report, April 24, (2017). Project Number 17M16 (web)

Taghiyev, E. I. (2001). the patent of the Azerbaijan Republic I 2001 0142, October 02, 2001

Taghiyev, E. I. (2003). the patent of the Azerbaijan Republic I 2003 0210, October 30, 2003

Taghiyev, E. I. (2006). Technology of complex processing without waste of alunite ores, Baku, Elm, 504 pages (scientific monograph in Russian).

Taghiyev, E. I., Babaev, I. S., Radzhabli, S. B., Khudiyev, A. T., \& Aliev, T. B. (1981). The USSR certificate of authorship \#872456 (June 15, 1981) 
Appendix A. Technological scheme of soda-alkaline method of processing of alunite ores with approximate quantities of materials for alunite ore enriching by flotation ( $60 \%$ alunite)

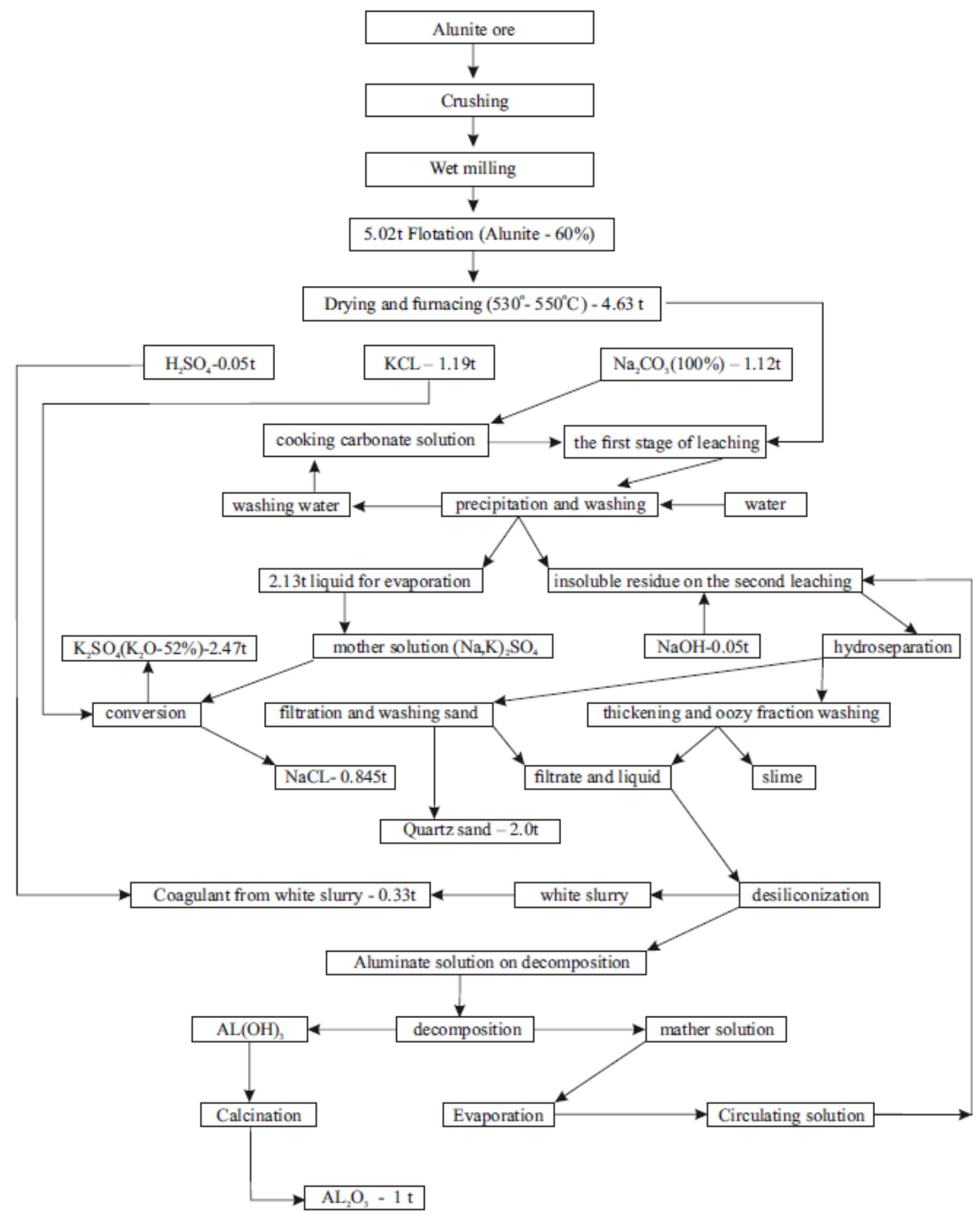


Appendix B. Technological scheme $-1^{\text {st }}$ stage of implementation of soda-alkaline technology of alunite ore processing

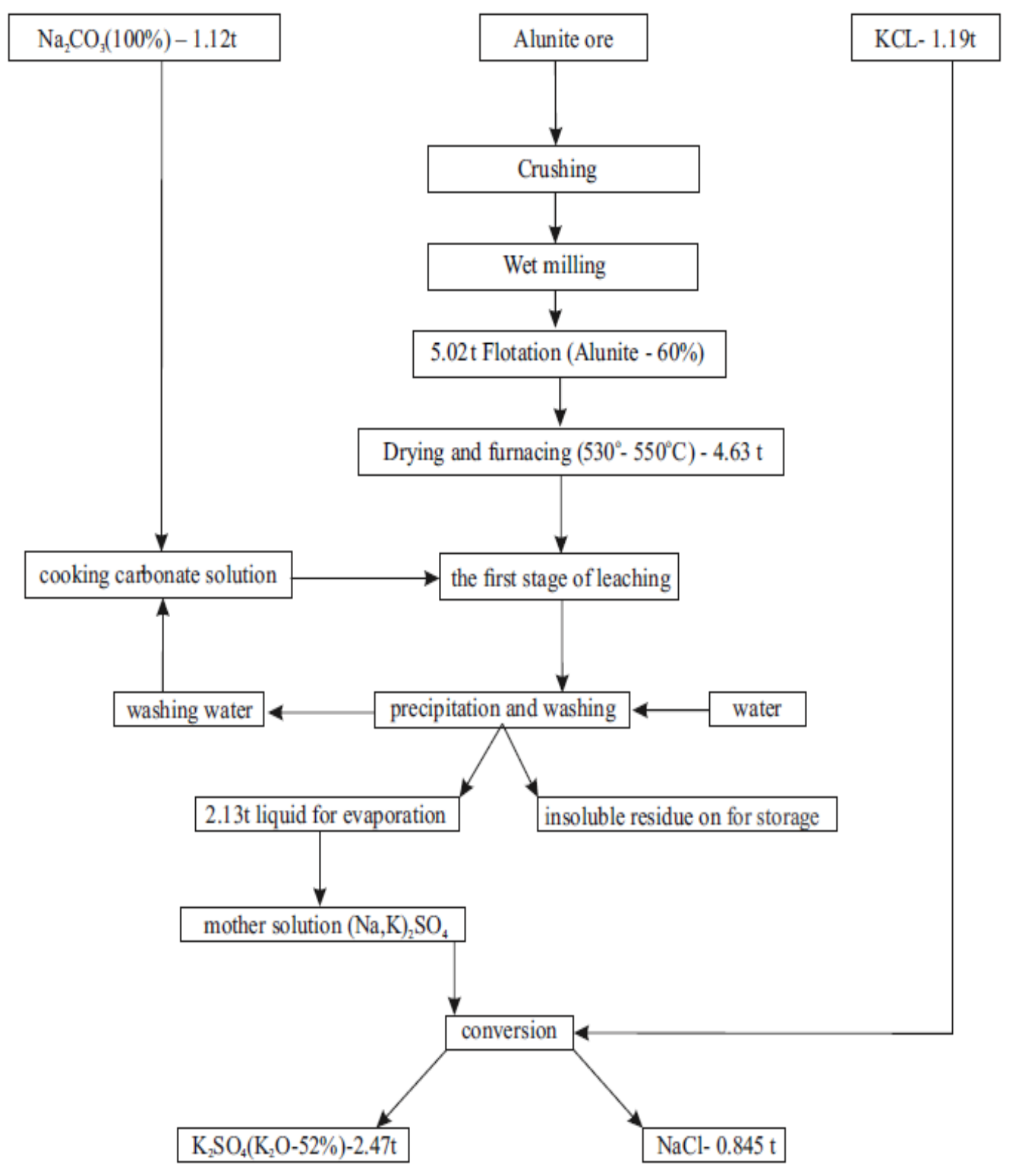

\section{Copyrights}

Copyright for this article is retained by the author(s), with first publication rights granted to the journal.

This is an open-access article distributed under the terms and conditions of the Creative Commons Attribution license (http://creativecommons.org/licenses/by/4.0/). 